\title{
Decreased nucleotide excision repair in steatotic livers associates with myeloperoxidase- immunoreactivity.
}

Citation for published version (APA):

Schults, M. A. C., Nagle, P. W., Rensen, S. S. M., Godschalk, R. W. L., Munnia, A., Peluso, M., Claessen, S. M., Greve, J. W., Driessen, A. L. C., Verdam, F. J., Buurman, W. A., van Schooten, F. J., \& Chiu, R. K. (2012). Decreased nucleotide excision repair in steatotic livers associates with myeloperoxidaseimmunoreactivity. Mutation Research-Fundamental and Molecular Mechanisms of Mutagenesis, 736(1-2), 75-81. https://doi.org/10.1016/j.mrfmmm.2011.11.001

Document status and date:

Published: 01/08/2012

DOI:

10.1016/j.mrfmmm.2011.11.001

Document Version:

Publisher's PDF, also known as Version of record

\section{Document license:}

Taverne

Please check the document version of this publication:

- A submitted manuscript is the version of the article upon submission and before peer-review. There can be important differences between the submitted version and the official published version of record.

People interested in the research are advised to contact the author for the final version of the publication, or visit the DOI to the publisher's website.

- The final author version and the galley proof are versions of the publication after peer review.

- The final published version features the final layout of the paper including the volume, issue and page numbers.

Link to publication

\footnotetext{
General rights rights.

- You may freely distribute the URL identifying the publication in the public portal. please follow below link for the End User Agreement:

www.umlib.nl/taverne-license

Take down policy

If you believe that this document breaches copyright please contact us at:

repository@maastrichtuniversity.nl

providing details and we will investigate your claim.
}

Copyright and moral rights for the publications made accessible in the public portal are retained by the authors and/or other copyright owners and it is a condition of accessing publications that users recognise and abide by the legal requirements associated with these

- Users may download and print one copy of any publication from the public portal for the purpose of private study or research.

- You may not further distribute the material or use it for any profit-making activity or commercial gain

If the publication is distributed under the terms of Article $25 \mathrm{fa}$ of the Dutch Copyright Act, indicated by the "Taverne" license above, 


\title{
Mutation Research/Fundamental and Molecular Mechanisms of Mutagenesis
}

journal homepage: www.elsevier.com/locate/molmut Community address: www.elsevier.com/locate/mutres

\section{Decreased nucleotide excision repair in steatotic livers associates with myeloperoxidase-immunoreactivity}

\author{
Marten A. Schults a ${ }^{a}$ Peter W. Nagle ${ }^{a}$, Sander S. Rensen ${ }^{b}$, Roger W. Godschalk ${ }^{a}$, Armelle Munnia $^{c}$, \\ Marco Peluso $^{c}$, Sandra M. Claessen ${ }^{d}$, Jan W. Greve ${ }^{b}$, Ann Driessen ${ }^{\mathrm{e}}$, Froukje J. Verdam ${ }^{\mathrm{b}}$, \\ Wim A. Buurman ${ }^{b}$, Frederik J. van Schooten ${ }^{\mathrm{a}}$, Roland K. Chiu ${ }^{\mathrm{a}, *}$ \\ a Department of Toxicology, NUTRIM-School for Nutrition, Toxicology and Metabolism, Maastricht University Medical Centre, PO Box 616, 6200 MD Maastricht, The Netherlands \\ ${ }^{\mathrm{b}}$ Department of Surgery, NUTRIM-School for Nutrition, Toxicology and Metabolism, Maastricht University Medical Centre, PO Box 616, 6200 MD Maastricht, The Netherlands \\ ${ }^{\mathrm{c}}$ Cancer Risk Factor Branch, ISPO Cancer Prevention and Research Institute, Via Cosimo il Vecchio 2, 50139 Florence, Italy

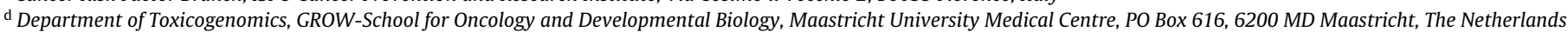 \\ e Department of Pathology, NUTRIM-School for Nutrition, Toxicology and Metabolism, Maastricht University Medical Centre, PO Box 616, 6200 MD Maastricht, The Netherlands
}

\section{A R T I C L E I N F O}

\section{Article history:}

Received 4 May 2011

Received in revised form 17 October 2011

Accepted 1 November 2011

Available online 7 November 2011

\section{Keywords:}

Nucleotide excision repair

Myeloperoxidase

Nonalcoholic steatohepatitis

Chronic inflammation

Oxidative stress

\begin{abstract}
A B S T R A C T
Chronic inflammation is characterized by the influx of neutrophils and is associated with an increased production of reactive oxygen species that can damage DNA. Oxidative DNA damage is generally thought to be involved in the increased risk of cancer in inflamed tissues. We previously demonstrated that activated neutrophil mediated oxidative stress results in a reduction in nucleotide excision repair (NER) capacity, which could further enhance mutagenesis. Inflammation and oxidative stress are critical factors in the progression of nonalcoholic fatty liver disease that is linked with enhanced liver cancer risk. In this report, we therefore evaluated the role of neutrophils and the associated oxidative stress in damage recognition and DNA repair in steatotic livers of 35 severely obese subjects with either nonalcoholic steatohepatitis (NASH) $(n=17)$ or steatosis alone $(n=18)$. The neutrophilic influx in liver was assessed by myeloperoxidase (MPO) staining and the amount of oxidative DNA damage by measuring $\mathrm{M}_{1} \mathrm{dG}$ adducts. No differences in $M_{1} d G$ adduct levels were observed between patients with or without NASH and also not between individuals with high or low MPO immunoreactivity. However, we found that high expression of MPO in the liver, irrespective of disease status, reduced the damage recognition capacity as determined by staining for histone $2 \mathrm{AX}$ phosphorylation $(\gamma \mathrm{H} 2 \mathrm{AX})$. This reduction in $\gamma \mathrm{H} 2 \mathrm{AX}$ formation in individuals with high MPO immunoreactivity was paralleled by a significant decrease in NER capacity as assessed by a functional repair assay, and was not related to cell proliferation. Thus, the observed reduction in NER capacity upon hepatic inflammation is associated with and may be a consequence of reduced damage recognition. These findings suggest a novel mechanism of liver cancer development in patients with nonalcoholic fatty liver disease.
\end{abstract}

(C) 2011 Elsevier B.V. All rights reserved.

\section{Introduction}

Hepatic inflammation plays a fundamental role in liver cancer development [1] and is increasingly observed in parallel with

Abbreviations: $\quad \gamma \mathrm{H} 2 \mathrm{AX}$, histone 2AX phosphorylation; $\mathrm{H}_{2} \mathrm{O}_{2}$, hydrogen peroxide; HCC, hepatocellular carcinoma; $\mathrm{HOCl}$, hypochlorous acid; $\mathrm{M}_{1} \mathrm{dG}$, 3(2-deoxy- $\beta$-D-erythro-pentofuranosyl)pyrimido [1,2- $\alpha]$ purin-10(3H)-one; MPO, myeloperoxidase; NAFLD, nonalcoholic fatty liver disease; NASH, nonalcoholic steatohepatitis; NER, nucleotide excision repair; ROS, reactive oxygen species.

This work was supported by the Province of Limburg, The Netherlands, by Senter Novem Innovatiegerichte Onderzoeks Programma's Genomics grant IGE05012, and by Associazione Italiana per la Ricerca sul Cancro, Milan, Italy.

* Corresponding author. Current address: Department of Radiation Oncology, University Medical Center Groningen, University of Groningen, P.O. Box 30001, 9700 RB Groningen, The Netherlands. Tel.: +31 43388 1968; fax: +31 433884146.

E-mail address: r.k.chiu@med.umcg.nl (R.K. Chiu). the high prevalence of nonalcoholic fatty liver disease (NAFLD). NAFLD is characterized by the accumulation of fat within the liver. Increased levels of hepatic free fatty acids are thought to initiate an inflammatory response culminating in the recruitment of neutrophils and other leukocytes [2,3] and eventually in the progression of the benign steatotic stage of NAFLD to the more advanced stages of nonalcoholic steatohepatitis (NASH), fibrosis, and cirrhosis [4,5]. Importantly, there is a link between NASH and the development of hepatocellular carcinoma (HCC), which accounts for more than $80 \%$ of primary liver cancer cases [6]. Several groups have suggested that HCC could in fact be the endpoint of NASH $[7,8]$. Although the mechanisms by which NASH can lead to the development of HCC are not fully understood, it is known that development of HCC occurs in a significant proportion of people with cirrhosis [6]. Oxidative stress caused by reactive oxygen species (ROS) is an important characteristic of cancer development [9]. Furthermore, many animal studies have revealed a 
link between oxidative stress and increased hepatocarcinogenesis by inducing [10] and promoting tumors [11] and causing DNA damage [12].

Inflammation occurs when pro-inflammatory cytokines and chemokines at a site of injury or infection release chemical signals causing an influx of inflammatory cells including neutrophils, monocytes, and eosinophils. The influx of some of these cells results in prolonged production of ROS such as nitric oxide, superoxide, hydrogen peroxide $\left(\mathrm{H}_{2} \mathrm{O}_{2}\right)$ [13], and in the release of myeloperoxidase (MPO). ROS accumulation results in various forms of DNA damage via oxidation, nitration, depurination, or deamination. In addition, it leads to DNA strand breaks and sister chromatid exchanges, all of which can lead to increased mutagenesis and carcinogenesis [14]. MPO is an important enzyme abundantly present in neutrophils and involved in the catalysis of $\mathrm{H}_{2} \mathrm{O}_{2}$ to hypochlorous acid ( $\mathrm{HOCl}$ ) [15]. $\mathrm{HOCl}$ contributes to host tissue damage at sites of inflammation through reactions with a wide range of biological substrates [16]. It damages proteins by causing side-chain modification, backbone fragmentation, and cross-linking [17]. Furthermore, Spencer et al. showed that $\mathrm{HOCl}$ is involved in DNA damage in epithelial cells by oxidizing pyrimidine bases and chlorination of cytosine [18]. Interestingly, we previously showed that NASH is associated with increased MPO activity [19].

Recently we have also demonstrated that MPO-derived $\mathrm{HOCl}$ mediates the strong inhibition of nucleotide excision repair (NER) capacity in A549 lung cancer cells by activated neutrophils [20]. We confirmed that acute lung inflammation caused a $\sim 50 \%$ reduction in NER capacity due to down-regulation of the NER associated genes XPA and ERCC4 in mice. However, Mpo-deficient mice were shown to also have a reduction in NER capacity, suggesting that the suppression of NER in vivo was not dependent on MPO release, but rather due to ROS following the influx of neutrophils [21]. Previous studies within our group have also indicated a role for oxidative stress in reduction of NER in colon tissue of newborn piglets, which could be reversed by administration of antioxidants [22]. This suggests that release of MPO is not the major cause of decreased NER capacity, but it still plays a role in increasing the risk of cancer in inflammation related diseases. Furthermore, reduced expression of NER related genes, such as ERCC1, has been linked to development of lung cancer [23]. NER-deficient individuals are at a significantly higher risk of developing certain forms of cancer, including those associated with chronic inflammation [23,24], as there is no 'backup' pathway for NER malfunction [25].

The mechanisms by which inflammation and the subsequent influx of neutrophils can cause the inhibition of NER, and how this increases the risk of cancer, are not yet elucidated. Potential mechanisms include a failure to recognise the damage; downregulation of NER related genes, or inhibition of the repair related proteins. Large amounts of ROS are produced during inflammatory NAFLDs such as NASH that put patients at a higher risk of developing HCC, which could be the result of lower NER capacity. In this report, we demonstrate that there is a decrease in damage recognition in subjects with NAFLD and high MPO expression, which correlates with a decrease in NER capacity.

\section{Methods}

\subsection{Liver specimens}

Human liver specimens were obtained during bariatric surgery from 35 severely obese patients (body mass index $>40$ ). None of the patients had suffered from viral hepatitis or autoimmune-related disorders or reported excessive alcohol consumption ( $>20 \mathrm{~g} /$ day). Biopsies were fixed in formaline stained and analysed to differentiate liver samples in $<33 \%$ steatosis without inflammation (steatosis group) and NASH as previously described [19]. As we have previously shown that there is a clear relation between extracellular MPO activity and neutrophil influx in inflamed tissues [26], MPO in the liver was detected by immunohistochemical staining (see
Table 1

Clinical characteristics of patients studied.

\begin{tabular}{llllll}
\hline & \multicolumn{2}{l}{ Low MPO } & & \multicolumn{2}{l}{ High MPO } \\
\cline { 2 - 3 } & Steatosis & NASH & & Steatosis & NASH \\
\hline No. of patients & 9 & 8 & & 9 & 9 \\
Sex (female/male) & $5 / 4$ & $3 / 5$ & & $7 / 2$ & $9 / 0$ \\
Age (years) & $48 \pm 3.5$ & $41 \pm 3.8$ & & $45 \pm 2.4$ & $52 \pm 2.5$ \\
BMI (kg/m ${ }^{2}$ ) & $44 \pm 2.4$ & $51 \pm 3.0$ & & $44 \pm 2.8$ & $56 \pm 4.3$ \\
Fasting glucose & $6.3 \pm 0.4$ & $5.6 \pm 0.1$ & & $5.7 \pm 0.2$ & $8.3 \pm 0.4$ \\
$\quad($ mmol/L) & & & & \\
ALT (IU) & $26.0 \pm 6.5$ & $21.1 \pm 3.2$ & & $23.7 \pm 3.0$ & $25.7 \pm 3.3$ \\
AST (IU) & $22.8 \pm 3.8$ & $26.6 \pm 4.2$ & & $18.2 \pm 2.3$ & $27.2 \pm 3.8$ \\
\hline
\end{tabular}

Section 2.4) and was used as a measure for MPO activity. Patient characteristics are summarized in Table 1. This study was approved by the Medical Ethical Board of the Maastricht University Medical Centre in line with the ethical guidelines of the 2008 Declaration of Seoul, and informed consent in writing was obtained from each subject.

\subsection{Quantitative real-time PCR}

Total RNA was isolated from $50 \mathrm{mg}$ liver tissue by homogenization in Tri-reagent (Sigma), according to the manufacturer's instructions. RNA (750 ng) was converted to cDNA using the iScript cDNA synthesis kit (Bio-Rad). Quantitative real-time PCR was performed with the Sensimix Sybr Green (Quantace, London, UK) and the MyiQ Single Color RT-PCR detection system (Biorad). The MyiQ Software system (Biorad) was used for data analysis. Using the $2^{-\Delta \Delta \mathrm{Ct}}$ method, relative gene expression (fold increase) was calculated. All data were normalized to the housekeeping genes $\beta$-actin and cyclophilin A. Sequences of the used PCR primers are listed in Table 2.

\subsection{Quantification of $M_{1} d G$}

After removal of the aqueous phase during RNA isolation using Trizol (Invitrogen), the remaining phases were used for DNA isolation according to the manufacturer's protocol. DNA was resuspended in $100 \mu \mathrm{L} \mathrm{H}_{2} \mathrm{O}$. The quantity and quality of DNA was measured using the Nanodrop 1000 (Thermo Scientific). The ${ }^{32} \mathrm{P}$-postlabelling technique was used to analyse the levels of 3(2-deoxy- $\beta$-D-erythro-pentofuranosyl)pyrimido [1,2- $\alpha]$ purin-10(3H)-one $\left(\mathrm{M}_{1} \mathrm{dG}\right)$

Table 2

Primer sequences for real time RT-PCR.

\begin{tabular}{|c|c|}
\hline Gene & Sequence $5^{\prime} \rightarrow 3^{\prime}$ \\
\hline$\beta$-Actin & $\begin{array}{l}\text { Forward primer } \\
\text { CCTGGCACCCAGCACAAT } \\
\text { Reverse primer } \\
\text { GCCGATCCACACGGAGTACT }\end{array}$ \\
\hline Cyclophilin A & $\begin{array}{l}\text { Forward primer } \\
\text { TTCCTGCTTTCACAGAATTATTCC } \\
\text { Reverse primer } \\
\text { GCCACCAGTGCCATTATGG }\end{array}$ \\
\hline XPA & $\begin{array}{l}\text { Forward primer } \\
\text { CCGACAGGAAAACCGAGAAA } \\
\text { Reverse primer } \\
\text { TTCCACACGCTGCTTCTTACTG }\end{array}$ \\
\hline $\mathrm{XPC}$ & $\begin{array}{l}\text { Forward primer } \\
\text { CCCAGCCCGCTTTACCA } \\
\text { Reverse primer } \\
\text { TGCATTAACTGTAAATGTTCCAATGA }\end{array}$ \\
\hline ERCC4 & $\begin{array}{l}\text { Forward primer } \\
\text { CACCTCCCTCGCCGTGTA } \\
\text { Reverse primer } \\
\text { CGCAAATATAACACCACCTTGTG }\end{array}$ \\
\hline ERCC5 & $\begin{array}{l}\text { Forward primer } \\
\text { GCATGAAATCTTGACTGATATGAAAGA } \\
\text { Reverse primer } \\
\text { TAAGCAAGCCTTTGAGTTGGTACTG }\end{array}$ \\
\hline ERCC1 & $\begin{array}{l}\text { Forward primer } \\
\text { ACCCCTCGACGAGGATGAG } \\
\text { Reverse primer } \\
\text { CAGTGGGAAGGCTCTGTGTAGA }\end{array}$ \\
\hline
\end{tabular}


adducts, as previously reported [27]. $\mathrm{M}_{1} \mathrm{dG}$ adduct separation was carried out by PEI-cellulose TLC chromatography according to published conditions [28]. Detection and quantification of $\mathrm{M}_{1} \mathrm{dG}$ adducts and total nucleotides were obtained by phosphor imaging technology (Typhoon 9210, Amersham) and ImageQuant software (Molecular Dynamics, Sunnyvale, CA). After background subtraction, the levels of DNA adducts were expressed as relative adduct labelling $(\mathrm{RAL}=$ adducted nucleotides/total nucleotides). Standard MDA modified [29] and unmodified DNA were routinely processed in the analysis as controls.

\subsection{Immunohistochemistry}

MPO abundance was detected by immunohistochemical staining using polyclonal rabbit anti-human MPO antiserum (dilution 1:1000; Dako) as a primary antibody and semi-quantitative evaluation of MPO positive cells was performed on a four-point scale by two independent observers [19]. In the present study we used the patients with hardly any MPO positive cells (category 1) versus those who contain a large amount of MPO positive cells in their liver (category 4). For the $\gamma \mathrm{H} 2 \mathrm{AX}$ and Ki-67 staining, paraffin embedded tissue sections were deparaffinized and rehydrated 3 times for $10 \mathrm{~min}$ in xylol, twice for $5 \mathrm{~min}$ in $100 \% \mathrm{EtOH}$, twice for $5 \mathrm{~min}$ in $96 \% \mathrm{EtOH}, 5 \mathrm{~min}$ in $70 \% \mathrm{EtOH}$ and $5 \mathrm{~min}$ in PBS. Slides were heated 3 times for $5 \mathrm{~min}$ in $0.01 \mathrm{M}$ citrate buffer ( $\mathrm{pH} 6.0$ ) followed by treatment with $2 \% \mathrm{H}_{2} \mathrm{O}_{2}$ in methanol for $30 \mathrm{~min}$ at room temperature. Nonspecific binding was blocked with $3 \% \mathrm{BSA} / \mathrm{PBS}$ for $30 \mathrm{~min}$ at room temperature and slides were subsequently incubated for $1 \mathrm{~h}$ at room temperature with a 1:1000 dilution of the primary antibody, mouse anti- $\gamma \mathrm{H} 2 \mathrm{AX}$ JBW301 (Upstate, Billerica, MA) or mouse anti-human Ki-67 (Dako). The secondary antibody, biotinylated Rabbit anti Mouse P0161 (Dako) was diluted in 1\% BSA/PBS for $1 \mathrm{~h}$ at $37^{\circ} \mathrm{C}$ followed by BrightVision+ (Immunologic, The Netherlands) according to the manufacturer's instructions. Slides were incubated with DAB $(0.7 \mathrm{mg} / \mathrm{ml})$ and urea $(2 \mathrm{mg} / \mathrm{ml})$ for $7 \mathrm{~min}$ and counterstained with haematoxylin for $1 \mathrm{~min}$. Slides were dehydrated for $5 \mathrm{~min}$ in $70 \% \mathrm{EtOH}$ after washing with tap water, twice for $5 \mathrm{~min}$ in $96 \% \mathrm{EtOH}$, twice for $5 \mathrm{~min}$ in $100 \% \mathrm{EtOH}$ and twice for $10 \mathrm{~min}$ in xylol. Finally the slides were mounted in Entellan (Merck). At least 100 randomly selected cells per slide were microscopically scored blindly. For the $\gamma \mathrm{H} 2 \mathrm{AX}$ staining, cells were graded on a gradual scale in which 0 was considered no staining (only counterstaining visible) and 4 was considered highly positive in which over $80 \%$ of the nucleus was brown. For the Ki-67 staining, the percentage of positive cells (brown nucleus) was determined.

\subsection{Measurement of NER capacity}

To measure NER capacity in the liver samples, we applied a previously validated modified comet assay [30] which measures the ability of NER-related enzymes that are present in "test" extracts, to incise substrate DNA containing BPDE-DNA adducts. The substrate nucleoids were prepared from untreated A549 cells (human epithelial lung carcinoma cells) obtained from the American Tissue Culture Collection (ATCC, Rockville, MD). The cells were cultured in DMEM supplemented with $10 \%$ heat-inactivated FCS and $1 \%$ penicillin/streptomycin and maintained at $37{ }^{\circ} \mathrm{C}$ in a $5 \% \mathrm{CO}_{2}$ atmosphere. A549 cells were embedded in LMP agarose on glass microscope slides and subsequently lysed overnight in cold $\left(4^{\circ} \mathrm{C}\right)$ lysis buffer $(2.5 \mathrm{M} \mathrm{NaCl}, 0.1 \mathrm{M}$ EDTA, $0.01 \mathrm{M}$ Tris, $0.25 \mathrm{M} \mathrm{NaOH}$ plus $1 \%$ Triton $\mathrm{X}-100$ and $10 \%$ DMSO). The resulting nucleoids were then either exposed to $1 \mu \mathrm{M}$ BPDE (NCI Chemical Carcinogen Reference Standard Repository, Midwest Research Institute, Kansas City, MO) in PBS or vehicle control (DMSO, 0.5\%) for $30 \mathrm{~min}$ at $4{ }^{\circ} \mathrm{C}$. To prepare protein/enzyme extracts, ground frozen liver tissues were thawed and resuspended in $45 \mathrm{mM}$ HEPES, $0.4 \mathrm{M} \mathrm{KCl}, 1 \mathrm{mM}$ EDTA, $0.1 \mathrm{mM}$ dithiothreitol, $10 \%$ glycerol, adjusted to $\mathrm{pH} 7.8$ using $\mathrm{KOH}$. Resulting aliquots were snap-frozen, thawed again and $30 \mu \mathrm{l}$ of $1 \%$ Triton X-100 in buffer A per $100 \mu \mathrm{l}$ of extract was added. Protein concentrations were determined by the BioRAD DC protein assay using bovine serum albumin as a standard. Tissue extracts were diluted to a concentration of $1 \mathrm{mg} / \mathrm{ml}$. Next, 4 volumes of $45 \mathrm{mM}$ HEPES, $0.25 \mathrm{mM}$ EDTA, $2 \%$ glycerol, $0.3 \mathrm{mg} / \mathrm{ml}$ BSA, adjusted to $\mathrm{pH} 7.8$ with $\mathrm{KOH}$ were added and $50 \mu \mathrm{l}$ of the mixture was added to the gel-embedded nucleoids and incubated for $20 \mathrm{~min}$ at $37^{\circ} \mathrm{C}$. Alkaline treatment ( $40 \mathrm{~min}$ ) and electrophoresis (30 min) were conducted as in the standard comet assay [31]. Comets were visualized using a Zeiss Axioskop fluorescence microscope and quantified as tail moment and percentage DNA in tail (tail intensity). Samples were tested in two independent incubations within each single experiment. On every slide, 50 cells were analysed randomly using the Comet assay III software program (Perspective Instruments, Haverhill, UK). The increased DNA strand breakage in the BPDE-modified nucleoids vs. the DMSO-treated nucleoids is indicative of the NER capacity of the cell extracts. The final repair capacity was calculated according to the method previously described [30] using both tail moment as well tail intensity.

\subsection{Statistical analysis}

Results are expressed as means \pm S.E. SPSS 15.0 was used for statistical analysis. The two-way ANOVA was used to determine the influence of MPO and NASH. To assess differences between four groups, a one-way analysis of variance test with
Dunnet's post hoc multiple comparison correction was used. Differences were considered to be statistically significant when $p<0.05$.

\section{Results}

\subsection{Inflammation in steatotic livers did not increase $M_{1} d G$ adduct levels}

To characterize the effect of NASH and/or MPO abundance, on the amount of ROS-induced DNA damage in the liver and $\mathrm{M}_{1} \mathrm{dG}$ adduct levels were determined. We were able to isolate DNA from 22 patients with steatosis. MPO expression in the liver tissue was determined and patients were divided into groups of low versus high MPO staining or steatosis alone versus NASH. There were no differences between the four groups regarding $\mathrm{M}_{1} \mathrm{dG}$ adduct levels (Fig. 1). This suggests that inflammation, as determined by the presence of MPO had no effect on hepatic DNA damage in NAFLD.

\subsection{Decreased phosphorylated $H 2 A X$ under high MPO expression in the liver}

Next, we stained for histone 2AX phosphorylation ( $\gamma \mathrm{H} 2 \mathrm{AX})$. Of 18 patients we were able to obtain liver samples for staining. Patients without NASH and low MPO expression had the highest $\gamma \mathrm{H} 2 \mathrm{AX}$ levels. A $\sim 52 \%$ decrease in semi-quantitative $\gamma \mathrm{H} 2 \mathrm{AX}$ levels was observed in the liver samples of patients with NASH and low MPO expression. Patients with high MPO expression had a further decrease towards $\sim 26 \%$ and $\sim 28 \%$, of the semi-quantitative $\gamma \mathrm{H} 2 \mathrm{AX}$ levels observed in patients with steatosis and NASH, respectively (Fig. 2). The patients with high MPO immunoreactivity showed a statistically significant decrease of $\sim 59 \%$ compared to the patients with low MPO staining, while patients with NASH had 19\% lower semi-quantitative $\gamma \mathrm{H} 2 \mathrm{AX}$ levels compared to patients without NASH.

\subsection{Proliferation is unaltered in steatotic livers upon inflammation}

One possible explanation for the differences found in phosphorylation of $\mathrm{H} 2 \mathrm{AX}$ is changes in proliferation of cells. Ki-67 staining of the same liver samples stained for $\gamma \mathrm{H} 2 \mathrm{AX}$ showed no difference between the four groups (Fig. 3). This suggests that the differences found for the $\gamma \mathrm{H} 2 \mathrm{AX}$ staining were unlikely to be the direct result of differences in proliferation status.

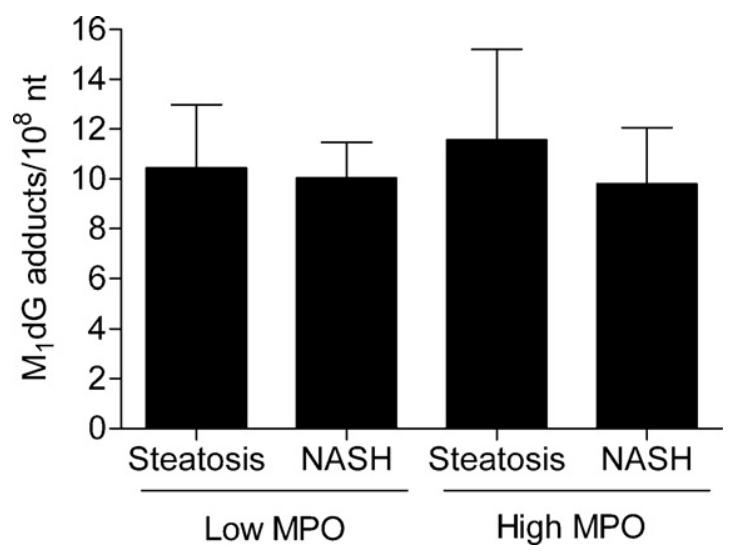

Fig. 1. Inflammation has no effect on $M_{1} d G$ DNA adduct levels. $M_{1} d G$ DNA adducts levels in human livers with low MPO levels and steatosis $(n=6)$ or NASH $(n=6)$ and high MPO levels and steatosis $(n=6)$ or NASH $(n=4)$ were determined by ${ }^{32} \mathrm{P}$-postlabeling and data was presented as amount of $\mathrm{M}_{1} \mathrm{dG}$ adducts per $10^{8}$ nucleotides. Values are mean \pm S.E. 

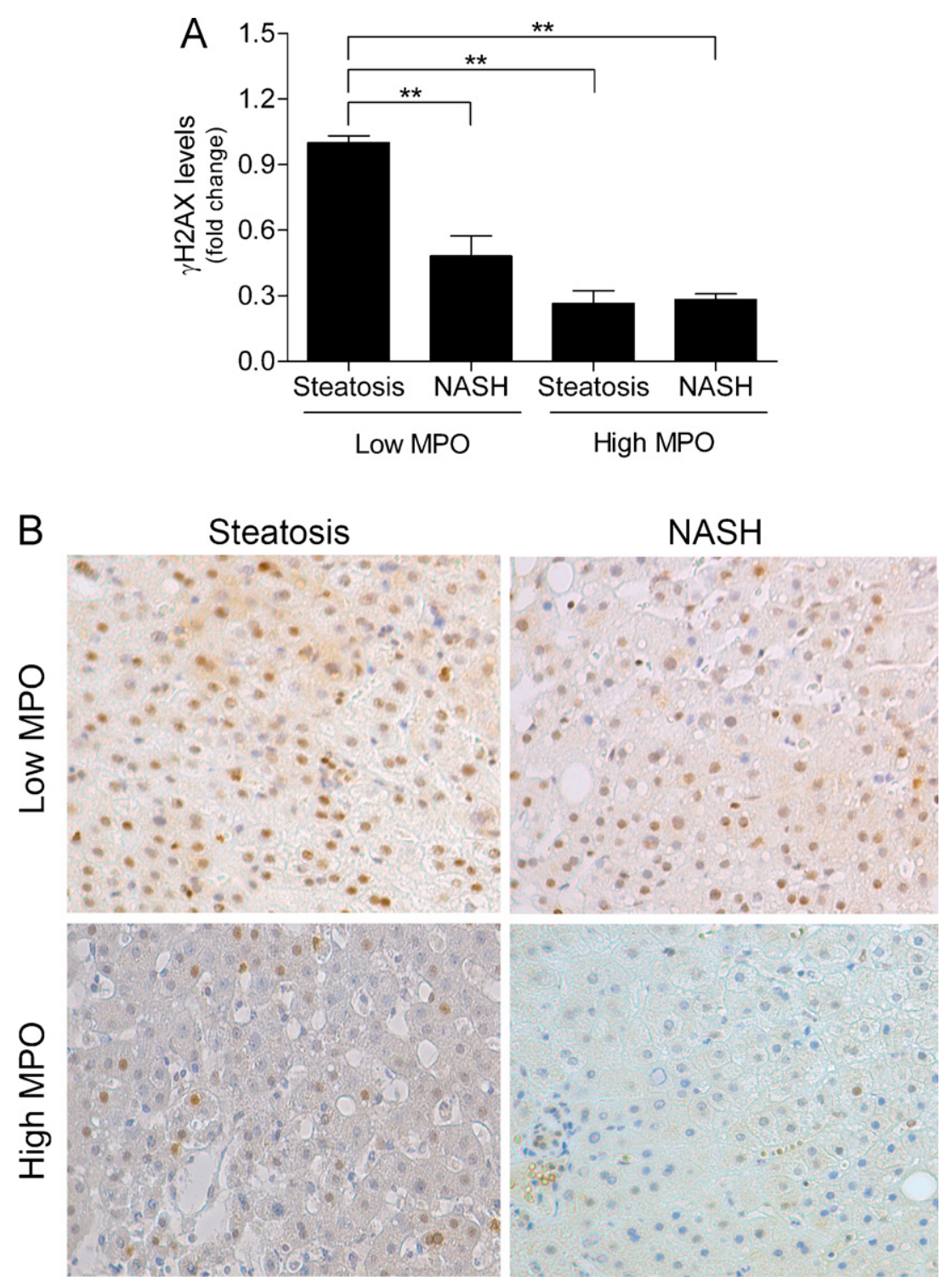

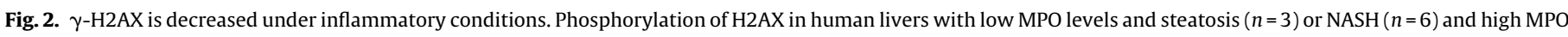

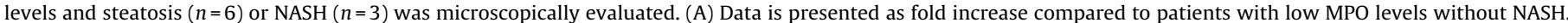

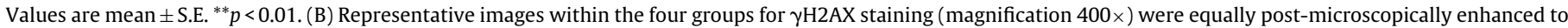
increase contrast for the brown $\gamma \mathrm{H} 2 \mathrm{AX}$ staining.

\subsection{Decreased NER gene expression in the liver of patients with} high MPO immunoreactivity

To investigate potential differences in DNA repair gene expression, the effect of MPO and NASH on the mRNA levels of 5 NER genes (XPA, XPC, ERCC4, ERCC5, and ERCC1) was determined (Table 3). Of 32 patients, mRNA levels could be determined. For both XPA and
ERCC4 gene expression, the highest mRNA levels were found in patients with low MPO staining without NASH. The relative amount of mRNA of these NER related genes decreased in patients with NASH and high MPO immunoreactivity; however the differences between the groups was only statistically significant for ERCC4. Patients with low MPO immunoreactivity were observed to have generally higher NER gene expression compared to patients with

Table 3

Relative NER gene expression in human livers.

\begin{tabular}{|c|c|c|c|c|c|c|}
\hline & & $\mathrm{XPA}$ & $\mathrm{XPC}$ & ERCC4 & ERCC5 & ERCC1 \\
\hline \multirow[t]{2}{*}{ Low MPO } & Steatosis & $1.00 \pm 0.10$ & $1.00 \pm 0.09$ & $1.00 \pm 0.05$ & $1.00 \pm 0.06$ & $1.00 \pm 0.08$ \\
\hline & $\mathrm{NASH}$ & $0.84 \pm 0.06$ & $1.05 \pm 0.07$ & $0.91 \pm 0.09$ & $1.24 \pm 0.08$ & $1.14 \pm 0.09$ \\
\hline \multirow[t]{2}{*}{ High MPO } & Steatosis & $0.80 \pm 0.05$ & $0.93 \pm 0.07$ & $0.88 \pm 0.06$ & $1.11 \pm 0.06$ & $1.15 \pm 0.11$ \\
\hline & NASH & $0.81 \pm 0.07$ & $0.84 \pm 0.10$ & $0.73 \pm 0.05^{*}$ & $0.84 \pm 0.09$ & $0.91 \pm 0.12$ \\
\hline
\end{tabular}

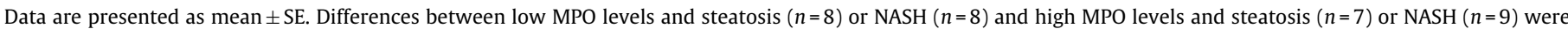
determined.

${ }^{*} p<0.05$. 


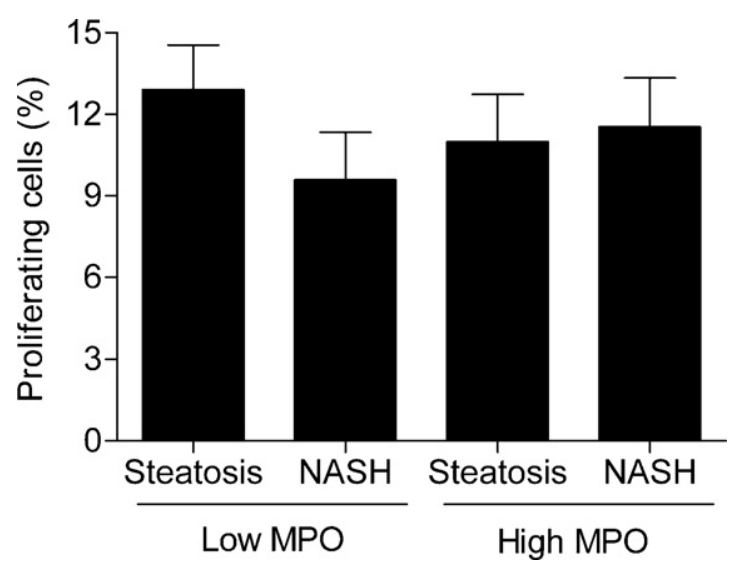

Fig. 3. No changes in proliferation under inflammatory conditions. Human liver samples of patients with low MPO levels and steatosis $(n=3)$ or NASH $(n=6)$ and high MPO levels and steatosis $(n=6)$ or NASH $(n=3)$ were stained for Ki-67 and percentage of proliferating cells was determined.

high MPO immunoreactivity. ERCC4 mRNA relative expression levels were significantly lower with $\sim 17 \%$. Patients with NASH also displayed a lower gene expression compared to patients without NASH. However, the difference in ERCC4 mRNA levels was not as large as compared to the differences in expression related to MPO.

\subsection{Decreased NER activity correlates with high MPO in the liver}

To investigate if the decreased $\gamma \mathrm{H} 2 \mathrm{AX}$ levels in patients with high MPO staining translated into a reduced functional NER capacity, we next studied NER capacity using a modified comet assay. NER capacity could be measured in liver samples isolated from 33 patients. Patients with low MPO expression without NASH had the highest repair capacity. A $\sim 26 \%$ and $\sim 30 \%$ lower repair capacity was observed in the liver of patients with low MPO immunoreactivity and NASH, when using tail moment and tail intensity values, respectively. The repair capacity further decreased in patients with high MPO expression to only $\sim 58 \%$ of the repair capacity of patients without NASH and low MPO staining (Fig. 4). The group with high MPO immunoreactivity showed a statistically significant decrease of $\sim 33 \%(p=0.02)$ and $\sim 30 \%(p=0.05)$ compared to the patients with low MPO expression, when using tail moment and tail intensity values, respectively. On the other hand, patients with NASH had a $\sim 14 \%(p=0.31)$ and $\sim 20 \%(p=0.20)$ lower repair capacity compared to patients without NASH (irrespective of MPO abundance), when using tail moment and tail intensity values, respectively. This difference was not statistically significant, suggesting that the presence of high levels of MPO-immunoreactive cells had the largest contribution to the observed lower levels of DNA repair.

\section{Discussion}

Chronic inflammation has been shown to play a role in the development of cancer in various organs, in part due to the recruitment of neutrophils at the site of inflammation resulting in enhanced levels of oxidative stress [14,32]. This oxidative stress may result in more DNA damage, a subsequent induction of mutation prone cells and ultimately increase in development in HCC [7,8,33-35]. Indeed, we have previously shown that NER activity was significantly impaired by neutrophil activation in lung cells [20]. There is circumstantial evidence that individuals with a reduced NER pathway capacity are at greater risk to develop cancer $[23,24]$. Therefore, we proposed that NER inhibition upon neutrophil activation and accumulation of mutations over time due to oxidative stress may play a role in the development of hepatocellular carcinomas associated with NASH.
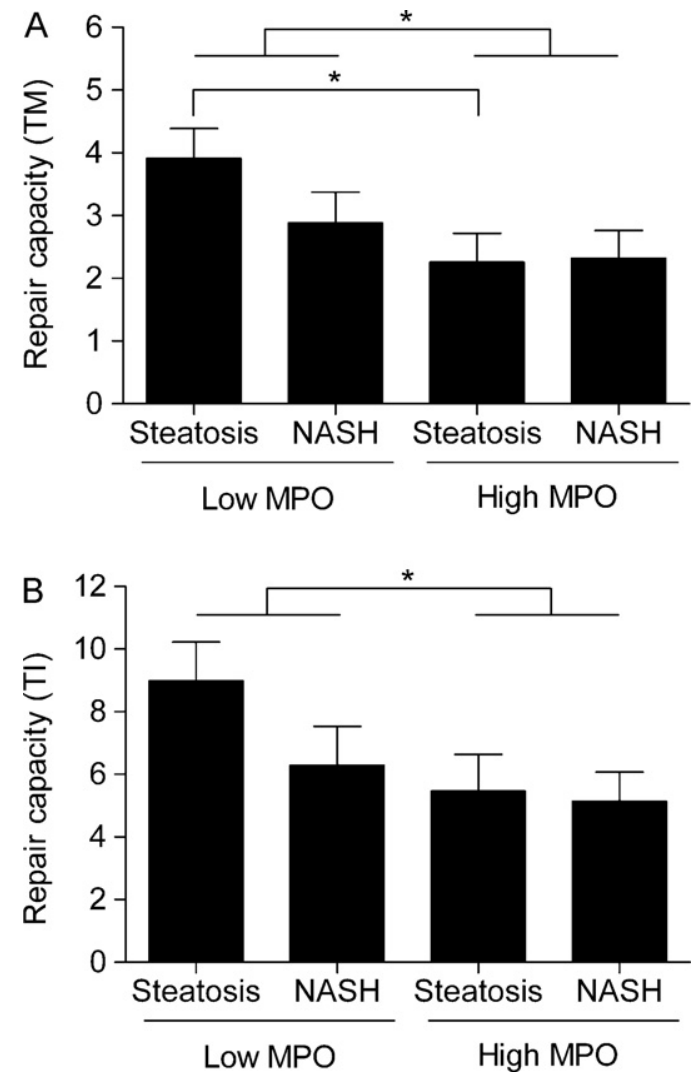

Fig. 4. NER capacity is decreased under inflammatory conditions. Repair capacity (A: calculated by using tail moment; B: calculated by using tail intensity) of cell extracts isolated from human livers was measured and differences between low MPO levels and steatosis $(n=8)$ or NASH $(n=8)$ and high MPO levels and steatosis $(n=9)$ or NASH $(n=8)$ were determined. Values are mean \pm S.E. ${ }^{*} p<0.05$.

To determine the amount of ROS induced DNA damage, $\mathrm{M}_{1} \mathrm{dG}$ adducts, a marker for oxidative damage, were measured. $\mathrm{M}_{1} \mathrm{dG}$ adducts result from ROS reacting with deoxyribose as well as malondialdehyde, a naturally occurring product of lipid peroxidation reacting with 2-deoxy-guanosine resulting in mutagenic and carcinogenic DNA adducts [36]. NER is the primary pathway that removes the damage caused by DNA helix distorting lesions, including $\mathrm{M}_{1} \mathrm{dG}$ adducts $[37,38]$. When DNA damage is not effectively removed, these lesions can be highly mutagenic [25,39,40]. In general, increased oxidative stress is seen as a trigger for the development of NASH from steatosis. However, several studies have observed similarly elevated levels of oxidative stress in steatosis and NASH [41-43]. Indeed, in this study, no significant differences in $\mathrm{M}_{1} \mathrm{dG}$ adduct levels were observed in relation to the presence of NASH neither to the inflammation as determined by MPO expression.

The phosphorylation of histone H2AX by the PI-3 kinases ATM, ATR and DNA-PK, is a well described marker for DNA damage. This occurs rapidly in response to double strand breaks (DSBs) [44], V(D)J recombination [45], replication fork blockage [46] and NER dependent DNA damage [47]. In liver cells, the observation of $\gamma \mathrm{H} 2 \mathrm{AX}$ is not likely linked to somatic recombination events. We therefore suggest that the reduced $\gamma \mathrm{H} 2 \mathrm{AX}$ is related to impairment of the recognition of DNA damage rather than absolute amount of damage, as the tissues showed similar DNA damage levels as inferred from the $\mathrm{M}_{1} \mathrm{dG}$ adducts (Fig. 1). Furthermore, $\gamma \mathrm{H} 2 \mathrm{AX}$ is also observed in $\mathrm{S}$ phase cells most likely due to DSBs or endogenous damage leading to stalled replication forks [48]. To determine whether the decrease in $\gamma \mathrm{H} 2 \mathrm{AX}$ that we observed with increased MPO (Fig. 2) resulted simply from changes in proliferation rate, we 
stained for Ki-67. As all groups showed similar levels of Ki-67 staining (Fig. 3), proliferation rates are unlikely to be the source of the differences in $\gamma \mathrm{H} 2 \mathrm{AX}$ staining.

To investigate whether MPO immunoreactivity in the liver or the NASH phenotype altered NER gene expression, the mRNA levels of XPA, XPC, ERCC1, ERCC4 and ERCC5, were determined. There was a consistent trend that repair genes were decreased in patients with high MPO immunoreactivity, but only ERCC4 showed significantly lower levels of expression in combination with conditions of high MPO expression. This is in agreement with previous studies on the regulation of NER genes in response to inflammation, where ERCC4 was down regulated in the presence of high MPO levels [21].

As DNA repair is often regulated in multiple manners in addition to transcriptional control, we sought to determine whether either NASH and/or higher MPO immunoreactivity impair overall functional NER. To this end, we used a previously validated modified comet assay, which predominantly assesses the cellular capacity in the recognition and incision phase of NER to remove bulky DNA adducts [30] and used both tail moment and to intensity to assess repair capacity. Steatotic liver samples with higher MPO expression had a significant decrease in the activity of this part of the NER pathway compared to the livers with lower expression of MPO using both the tail moment and tail intensity. Although the repair capacity was further reduced in the liver samples taken from NASH patients, the contribution of MPO appears to dominate. A small decrease in NER capacity was also observed in patients with NASH compared with subjects with steatosis alone; however this was not statistically significant. These results suggest that in human liver samples, NER is inhibited by increased MPO in vivo, similar to what we have previously described for lung cells in vitro [20]. The level of DNA adducts is the result of a balance between damage induction and its repair. Therefore, one would expect that the lower NER activity in patients with high MPO is accompanied by higher levels of the $\mathrm{M}_{1} \mathrm{dG}$ adducts. However, in this study we observed comparable levels between the four groups. Human data of both in vivo and in vitro models have demonstrated that cell death, particularly apoptosis, is increased in NAFLD and NASH patients [49]. If DNA repair is decreased in these patients as observed in our study, cell death of highly damaged cells could prevent DNA adduct levels to accumulate.

In this study, we have demonstrated that increased expression of MPO in the liver correlates with decreased NER capacity within the liver. Although the amount of inflammatory cells is much lower than the structural liver cells, a limitation of the study is that the differences found in DNA repair may partly be due to differences in the proportion of inflammatory cells that contribute to the tissue lysate, since whole tissue was used for the analysis. The observed decrease in $\gamma \mathrm{H} 2 \mathrm{AX}$ appears to be related to impairment of the recognition of DNA damage when MPO expression is high, as no significant reduction of cell proliferation and only a small change in NER gene expression transcription, was observed. Although in patients with NASH there is a decrease in both NER capacity and H2AX phosphorylation, the major component determining the repair capacity appears to be MPO-immunoreactivity. This suggests that increased influx of neutrophils and their activation, which is often associated with NASH, may play an important role in the development of HCC.

\section{Conflict of interest}

The authors declare that there are no conflicts of interest.

\section{References}

[1] P.A. Farazi, R.A. DePinho, Hepatocellular carcinoma pathogenesis: from genes to environment, Nat. Rev. Cancer 6 (2006) 674-687.
[2] G. Boden, Obesity and free fatty acids, Endocrinol. Metab. Clin. North Am. 37 (2008) 635-646, viii-ix.

[3] K. Yamaguchi, L. Yang, S. McCall, J. Huang, X.X. Yu, S.K. Pandey, S. Bhanot, B.P. Monia, Y.X. Li, A.M. Diehl, Inhibiting triglyceride synthesis improves hepatic steatosis but exacerbates liver damage and fibrosis in obese mice with nonalcoholic steatohepatitis, Hepatology 45 (2007) 1366-1374.

[4] J.J. Maher, P. Leon, J.C. Ryan, Beyond insulin resistance: innate immunity in nonalcoholic steatohepatitis, Hepatology 48 (2008) 670-678.

[5] H. Tilg, G.S. Hotamisligil, Nonalcoholic fatty liver disease: cytokine-adipokine interplay and regulation of insulin resistance, Gastroenterology 131 (2006) 934-945.

[6] E. Bugianesi, Non-alcoholic steatohepatitis and cancer, Clin. Liver Dis. 11 (2007) 191-207, x-xi.

[7] E. Bugianesi, N. Leone, E. Vanni, G. Marchesini, F. Brunello, P. Carucci, A. Musso, P. De Paolis, L. Capussotti, M. Salizzoni, M. Rizzetto, Expanding the natural history of nonalcoholic steatohepatitis: from cryptogenic cirrhosis to hepatocellular carcinoma, Gastroenterology 123 (2002) 134-140.

[8] J.P. Ong, Z.M. Younossi, Is hepatocellular carcinoma part of the natural history of nonalcoholic steatohepatitis? Gastroenterology 123 (2002) 375-378.

[9] S. Toyokuni, K. Okamoto, J. Yodoi, H. Hiai, Persistent oxidative stress in cancer, FEBS Lett. 358 (1995) 1-3.

[10] Y. Sanchez-Perez, C. Carrasco-Legleu, C. Garcia-Cuellar, J. Perez-Carreon, S. Hernandez-Garcia, M. Salcido-Neyoy, L. Aleman-Lazarini, S. Villa-Trevino, Oxidative stress in carcinogenesis. Correlation between lipid peroxidation and induction of preneoplastic lesions in rat hepatocarcinogenesis, Cancer Lett. 217 (2005) 25-32.

[11] Y. Dewa, J. Nishimura, M. Muguruma, M. Jin, M. Kawai, Y. Saegusa, T. Okamura T. Umemura, K. Mitsumori, Involvement of oxidative stress in hepatocellular tumor-promoting activity of oxfendazole in rats, Arch. Toxicol. 83 (2009) 503-511.

[12] J. Nishimura, Y. Dewa, M. Muguruma, Y. Kuroiwa, H. Yasuno, T. Shima, M. Jin, M. Takahashi, T. Umemura, K. Mitsumori, Effect of fenofibrate on oxidative DNA damage and on gene expression related to cell proliferation and apoptosis in rats, Toxicol. Sci. 97 (2007) 44-54.

[13] H. Maeda, T. Akaike, Nitric oxide and oxygen radicals in infection, inflammation, and cancer, Biochemistry (Mosc). 63 (1998) 854-865.

[14] A.M. Knaapen, N. Gungor, R.P. Schins, P.J. Borm, F.J. Van Schooten, Neutrophils and respiratory tract DNA damage and mutagenesis: a review, Mutagenesis 21 (2006) 225-236

[15] S.J. Klebanoff, Myeloperoxidase: friend and foe, J. Leukoc. Biol. 77 (2005) 598-625.

[16] M.J. Davies, C.L. Hawkins, D.I. Pattison, M.D. Rees, Mammalian heme peroxidases: from molecular mechanisms to health implications, Antioxid. Redox Signal. 10 (2008) 1199-1234.

[17] D.I. Pattison, M.J. Davies, Absolute rate constants for the reaction of hypochlorous acid with protein side chains and peptide bonds, Chem. Res. Toxicol. 14 (2001) 1453-1464.

[18] J.P. Spencer, M. Whiteman, A. Jenner, B. Halliwell, Nitrite-induced deamination and hypochlorite-induced oxidation of DNA in intact human respiratory tract epithelial cells, Free Radic. Biol. Med. 28 (2000) 1039-1050.

[19] S.S. Rensen, Y. Slaats, J. Nijhuis, A. Jans, V. Bieghs, A. Driessen, E. Malle, J.W. Greve, W.A. Buurman, Increased hepatic myeloperoxidase activity in obese subjects with nonalcoholic steatohepatitis, Am. J. Pathol. 175 (2009) 14731482.

[20] N. Gungor, R.W. Godschalk, D.M. Pachen, F.J. Van Schooten, A.M. Knaapen, Activated neutrophils inhibit nucleotide excision repair in human pulmonary epithelial cells: role of myeloperoxidase, FASEB J. 21 (2007) 2359-2367.

[21] N. Gungor, A. Haegens, A.M. Knaapen, R.W. Godschalk, R.K. Chiu, E.F. Wouters, F.J. van Schooten, Lung inflammation is associated with reduced pulmonary nucleotide excision repair in vivo, Mutagenesis 25 (2010) 77-82.

[22] S.A. Langie, P. Kowalczyk, B. Tudek, R. Zabielski, T. Dziaman, R. Olinski, F.J. van Schooten, R.W. Godschalk, The effect of oxidative stress on nucleotide-excision repair in colon tissue of newborn piglets, Mutat. Res. 695 (2010) 75-80.

[23] L. Cheng, M.R. Spitz, W.K. Hong, Q. Wei, Reduced expression levels of nucleotide excision repair genes in lung cancer: a case-control analysis, Carcinogenesis 21 (2000) 1527-1530.

[24] J.J. Latimer, J.M. Johnson, C.M. Kelly, T.D. Miles, K.A. Beaudry-Rodgers, N.A Lalanne, V.G. Vogel, A. Kanbour-Shakir, J.L. Kelley, R.R. Johnson, S.G. Grant, Nucleotide excision repair deficiency is intrinsic in sporadic stage I breast cancer, Proc. Natl. Acad. Sci. U. S. A. 107 (50) (2010) 21725-21730.

[25] T. Lindahl, R.D. Wood, Quality control by DNA repair, Science 286 (1999) 1897-1905.

[26] F.J. Van Schooten, A.W. Boots, A.M. Knaapen, R.W. Godschalk, L.M. Maas, P.J Borm, M. Drent, J.A. Jacobs, Myeloperoxidase (MPO) -463G->A reduces MPO activity and DNA adduct levels in bronchoalveolar lavages of smokers, Cancer Epidemiol. Biomarkers Prev. 13 (2004) 828-833.

[27] A. Munnia, F. Saletta, A. Allione, S. Piro, M. Confortini, G. Matullo, M. Peluso, 32P-post-labelling method improvements for aromatic compound-related molecular epidemiology studies, Mutagenesis 22 (2007) 381-385.

[28] A. Munnia, S. Bonassi, A. Verna, R. Quaglia, D. Pelucco, M. Ceppi, M. Neri, M Buratti, E. Taioli, S. Garte, M. Peluso, Bronchial malondialdehyde DNA adducts, tobacco smoking, and lung cancer, Free Radic. Biol. Med. 41 (2006) 1499-1505.

[29] H. Seto, T. Seto, T. Takesue, T. Ikemura, Reaction of malonaldehyde with nucleic acid. III. Studies of the fluorescent substances released by enzymatic digestion of nucleic acids modified with malonaldehyde, Chem. Pharm. Bull. (Tokyo) 34 (1986) 5079-5085. 
[30] S.A. Langie, A.M. Knaapen, K.J. Brauers, D. van Berlo, F.J. van Schooten, R.W. Godschalk, Development and validation of a modified comet assay to phenotypically assess nucleotide excision repair, Mutagenesis 21 (2006) 153-158.

[31] A.M. Knaapen, R.P. Schins, P.J. Borm, F.J. van Schooten, Nitrite enhances neutrophil-induced DNA strand breakage in pulmonary epithelial cells by inhibition of myeloperoxidase, Carcinogenesis 26 (2005) 1642-1648.

[32] L.M. Coussens, Z. Werb, Inflammation and cancer, Nature 420 (2002) 860867.

[33] E. Bugianesi, E. Vanni, G. Marchesini, NASH and the risk of cirrhosis and hepatocellular carcinoma in type 2 diabetes, Curr. Diab. Rep. 7 (2007) 175-180.

[34] E.E. Powell, W.G. Cooksley, R. Hanson, J. Searle, J.W. Halliday, L.W. Powell, The natural history of nonalcoholic steatohepatitis: a follow-up study of forty-two patients for up to 21 years, Hepatology 11 (1990) 74-80.

[35] Y. Zen, K. Katayanagi, K. Tsuneyama, K. Harada, I. Araki, Y. Nakanuma, Hepatocellular carcinoma arising in non-alcoholic steatohepatitis, Pathol. Int. 51 (2001) 127-131.

[36] L.J. Marnett, Lipid peroxidation-DNA damage by malondialdehyde, Mutat. Res. 424 (1999) 83-95.

[37] L.A. VanderVeen, M.F. Hashim, Y. Shyr, L.J. Marnett, Induction of frameshift and base pair substitution mutations by the major DNA adduct of the endogenous carcinogen malondialdehyde, Proc. Natl. Acad. Sci. U. S. A. 100 (2003) 14247-14252.

[38] K.A. Johnson, S.P. Fink, L.J. Marnett, Repair of propanodeoxyguanosine by nucleotide excision repair in vivo and in vitro, J. Biol. Chem. 272 (1997) 11434-11438.

[39] L.C. Gillet, O.D. Scharer, Molecular mechanisms of mammalian global genome nucleotide excision repair, Chem. Rev. 106 (2006) 253-276.

[40] A. Sancar, L.A. Lindsey-Boltz, K. Unsal-Kacmaz, S. Linn, Molecular mechanisms of mammalian DNA repair and the DNA damage checkpoints, Annu. Rev. Biochem 73 (2004) 39-85.
[41] H. Kojima, S. Sakurai, M. Uemura, H. Fukui, H. Morimoto, Y. Tamagawa, Mitochondrial abnormality and oxidative stress in nonalcoholic steatohepatitis, Alcohol. Clin. Exp. Res. 31 (2007) S61-S66.

[42] C. Loguercio, V. De Girolamo, I. de Sio, C. Tuccillo, A. Ascione, F. Baldi, G. Budillon, L. Cimino, A. Di Carlo, M.P. Di Marino, F. Morisco, F. Picciotto, L. Terracciano, R. Vecchione, V. Verde, C. Del Vecchio Blanco, Non-alcoholic fatty liver disease in an area of southern Italy: main clinical, histological, and pathophysiological aspects, J. Hepatol. 35 (2001) 568-574.

[43] S. Seki, T. Kitada, T. Yamada, H. Sakaguchi, K. Nakatani, K. Wakasa, In situ detection of lipid peroxidation and oxidative DNA damage in non-alcoholic fatty liver diseases, J. Hepatol. 37 (2002) 56-62.

[44] E.P. Rogakou, D.R. Pilch, A.H. Orr, V.S. Ivanova, W.M. Bonner, DNA doublestranded breaks induce histone H2AX phosphorylation on serine 139, J. Biol. Chem. 273 (1998) 5858-5868.

[45] H.T. Chen, A. Bhandoola, M.J. Difilippantonio, J. Zhu, M.J. Brown, X. Tai, E.P. Rogakou, T.M. Brotz, W.M. Bonner, T. Ried, A. Nussenzweig, Response to RAG-mediated VDJ cleavage by NBS1 and gamma-H2AX, Science 290 (2000) 1962-1965.

[46] M.E. Gagou, P. Zuazua-Villar, M. Meuth, Enhanced H2AX phosphorylation, DNA replication fork arrest, and cell death in the absence of Chk1, Mol. Biol. Cell 21 (2010) 739-752.

[47] T.M Marti, E. Hefner, L. Feeney, V. Natale, J.E. Cleaver, H2AX phosphorylation within the G1 phase after UV irradiation depends on nucleotide excision repair and not DNA double-strand breaks, Proc. Natl. Acad. Sci. U. S. A. 103 (2006) 9891-9896.

[48] I.M. Ward, J. Chen, Histone H2AX is phosphorylated in an ATR-dependent manner in response to replicational stress, J. Biol. Chem. 276 (2001) 47759-47762.

[49] M.V. Machado, H. Cortez-Pinto, Cell death and nonalcoholic steatohepatitis: where is ballooning relevant? Expert Rev. Gastroenterol. Hepatol. 5 (2011) 213-222. 